\title{
Improving Ability of Detecting Object Distance Through U-Qorselin Tools on Person with Visually Impaired
}

\author{
Marlina, Siti Qoniah \\ Universitas Negeri Padang, Indonesia \\ Email: marlina.muluk@gmail.com
}

\begin{abstract}
This article discusses the improvement of the ability of the person of visually impaired in detecting object distance through the use of U-Qoserlin tools. This research used R \& D method and continued with experiment. The subject of development experts consists of electrical engineering experts, orientation and mobility experts, and educational experts. The subject of the experiment consisted of five (5) the person of the visually impaired. The results of the study show that (1) U-Qoserlin tools are practical, feasible, useful and provide technological insights for the person of visually impaired; (2) the results of the data with the Mann Whitney test obtained the results of the smallest $U_{\text {hit }}$ value is 9 , and $U_{\text {tab }}$ at a significant level of $95 \%$ and $\alpha=0.05$ for $\mathrm{n}=6$ that is 5 . Thus, $\mathrm{U}$-Qoserlin tool effective in improving the ability to detect solid object spacing for the person of visually impaired. The implications of this study are that there should be a test of the effectiveness of U-Qoserlin on the number of the person of visually impaired more.
\end{abstract}

Keywords: U-qoserlin tools, object distance detector, the person of the visually impaired

\section{INTRODUCTION}

The eye is one of the most beautiful gifts that God gives us as a human. Through the eye, a human can enjoy and understand everything happening in the world. According to the World Health Organization, from a survey conducted in 2010, there are estimates that 285.389 million people in the world have a visual impairment. Their main problem is an orientation and mobility in an environment they don't know. There are a lot of efforts have been made to improve their mobility, for the example using technology. Many people with the serious visual impairment are in doubt in traveling by themselves.

Therefore, they need to use various tools to help their mobility. This is one of the orientation and mobility techniques that help people with visual impairment move dependently by utilizing their remaining sensory remains. Another way to help the mobility of people with impaired visual with guide dogs that have been specially trained to help people with visual impairment in moving with navigating nearby obstacles. However, this way has limitation like hard to understand the direction of the dog and the cost is very expensive. In addition, there is also the use of a white stick with a red stick. The white stick is a simple mechanical device used to detect static barriers in the field, surfaces, holes, and uneven surfaces through simple tactile force feedback. It is lightweight, easy to carry, but its reach is limited in size and cannot be used to detect dynamic barriers (Sharma \& Chatterji, 2014). If the person with visual impairment is not fully concentrated, then it can harm them in the daily activities of life by using this white stick.

The results of research in some people with visually impaired that has done by Qoniah (2016), they expect a simple tool that can detect objects around and help them in daily activities. The white sticks they use still have constraints and irregularities when crossing the road, many vehicles are passing at high speed. They expect if the creation of an object detector for people with visually impaired will facilitate them in performing daily activities, which is easy to carry anywhere, simple and practical.

There are some researches have been done to improve the mobility of people with visually impaired that rely on signal processing and sensor technology. As Subandi (2009) also created mobility aids for people with visually impaired based on electronics, this research produced a device capable of detecting objects up to a maximum distance of $200 \mathrm{~cm}$. Rahayu (2012) also makes designing and directional as well as object distance detection of people with vision impairment based on microcontroller. This study produces a tool that can detect the presence of objects in front of a visually impaired person with a sound output based on the microcontroller and wind direction directions for people with visually impaired. Tangdiongan et al. (2017) created a tool based on Arduino UNO - based on the microcontroller. This tool provides information in the form of estimation of the distance a hitch with the user in the form of sound and vibration information, ultrasonic 
sensors HC-SR04 is used as a detector obstacle, the information in the form of voice module used Catalaex $\mathrm{mp} 3$ player, Indicator obstacle in the form of vibration used cell motor vibrator. Dwiono et al. (2014) created a tool in the form of a stick, the information received by the user is in the form of vibrations received by the nerves in the hand. This tool uses a microcontroller system equipped with a proximity sensor, RFID reader, voice databases and RF wireless links, so hopefully can be manifested blind navigation tool that is effective and easy to operate, because the information provided is in the form of voice information in the form of place and distance. Aktanto (2016) designed a tool in the form of Electronic Travel Aids (ETA) that can detect obstacles in 3 parts of the body at once namely the head, chest, and legs. ETA is based on ATMEGA32 microcontroller and uses ultrasonic sensor HC-SR04. Multi Ultrasonic Electronic Tavel Aids is used as a guide tool for people with visually impaired.

Based on some research that has been done, it necessary to develop a more practical and simple tool called U - Qoserlin that is able to detect objects by setting the tool varied according to distance and there are components of the Atmega 8 microcontroller, ultrasonic sensor type SRF05, buzzer and use battery. The process of designing U-Qoserlin tools involves alumni of Electrical Engineering Department students of Universitas Negeri Padang. This tool is designed to help people with visually impaired know the environmental conditions and circumstances, as well as object distance by using electronic-based tools. The purpose of this article is: (1) to know the level of practicality, usefulness, and feasibility of U-Qoserlin tools that have been developed; and (2) to determine the effectiveness of the U-Qoserlin tools in improving the ability to detect objects on the person with visual impairment.

\section{METHOD}

This research used R\&D. The development procedure referred to Sugiyono (2014). The final result of R\&D is obtained by U-Qoserlin which is practical, useful, and feasible for people with visually impaired.

There are two subjects involved, the subject of the experts and the subject of the development. The subjects of the expert consist of three, the technical expert (lecturers of the Department of Electrical Engineering), orientation and mobility (lecturer of the Department Special Needs) and educational experts (lecturer of Department Educational Technology) for to test the practicality, usefulness, and feasibility of U-Qoserlin tools. These three subjects are defined through consideration of academic skills and qualifications. These three subjects are defined through consideration of academic skills and qualifications.
While the subject of development consists of people with visual impaired in SLB N 2 Padang, namely 1 boy and 1 girl, SLB Wacana Asih 2 people 2 boys, and 1 boy in SLB Gema Insani. The criteria for determining the subject of development are based on the consideration of experiencing total vision obstacles and have never used a white stick.

In this phase of development, the research was conducted in the laboratory of the Department of Special Education, while the stage of testing the effectiveness of the U -Qoserlin tool is done in SLB. Validation of U-Qoserlin tools is done by FGD (Focus Group Discussion), experts are asked to provide assessment and suggestions on the design of the U-Qoserlin tools. Expert validation uses a Likert-scale questionnaire (eg validity of validity, usability validation, and feasibility validation). Expert validation results serve as the basis for the perfection of U-Qoserlin tool. In the experimental stage, it is done by pretest using a white stick, followed by asking the five development subjects using U-Qoserlin tool in mobility, then done posttest. In the experimental stage, it is done by pretest using a white stick, followed by asking the five development subjects using U-Qoserlin tool in mobility, then done posttest. There are three aspects that are measured is the practicality, the ability to detect objects around, and the ability to detect the environment. More is presented in table 1 .

\section{FINDINGS AND DISCUSSION}

\section{Findings}

The results of research in the first stage is the development of the U-Qoserlin tool. This tool has the following components:

Microcontroller, small computer (special purpose computers) in an IC/chip microcontroller, there are CPU, memory, timer, serial and parallel communication channels, input ports, and ADC. A microcontroller is used for the controller that governs all processes.

Ultrasonic Sensors is an electric device that has a function as a sensor that works based on the principle of reflection of a sound wave to detect the existence of a certain object or object in front of it. The ultrasonic sensor consists of an ultrasonic transmitter circuit called a transmitter and an ultrasonic receiver circuit called a receiver.

The buzzer is an electronic component that serves to convert electrical vibrations into vibrations of sound. The working principle of the buzzer is similar to the loudspeaker.

The U-Qoserlin Toolkit development process is further validated by experts for practicality, usefulness, and eligibility. The validation process is presented in table 2 . 
Table 1. Question Validation of Practicality, Usability and Feasibility of U-Qoserlin Tools

\begin{tabular}{ccc}
\hline Aspect of Practicality & \multicolumn{2}{c}{ Rating } \\
& VP $\quad$ P $\quad$ LP \\
\hline
\end{tabular}

1. The level of attractiveness of design tools for object distance detection

2. Weight of product if brought by the person of visually impaired

3. Ease of use and operational levels

4. The product is rectangular, comfortable in grip

5. Simple and practical brought to the user

6. Simple and practical to keep in pocket, purse, pencil case

7. The product can be charged when the notification started to weak

\begin{tabular}{lc}
\hline Aspect of Use & \multicolumn{2}{c}{ Rating } \\
& VU U LU \\
\hline
\end{tabular}

1. The accuracy of identifying the solid object spacing is more than 1 meter

2. Ability of detect holes or gutters

3. Provide notification on the person with visual impairment if there is a bundle of land / embankment on the road

4. Helps detect the distance of objects in crowded places such as: in schools / campuses, rooms, markets, stations, tourist attractions

5. The product's ability to detect solid objects in new environments

\begin{tabular}{lcc}
\hline Aspect of Feasibility & \multicolumn{2}{c}{ Rating } \\
& VG G LG \\
\hline
\end{tabular}

1. If the user directs the product towards a sudden object may harm the user

2. Helping people with visual impairments in muddy roads, potholes

3. Ability to detect the distance of the vehicle with a person with visual impairment in the road

4. Detects solid objects that hang

5. The product's capabilities make it easy for people with visual impairments to climb up and down the stairs.
Table 2. U-Qoserlin Tool after Revision

\begin{tabular}{|c|c|c|}
\hline $\begin{array}{l}\text { The Re- } \\
\text { vised As- } \\
\text { pect }\end{array}$ & Revised Validator & Follow - up \\
\hline $\begin{array}{l}\text { Practical- } \\
\text { ity of U- } \\
\text { Qoserlin }\end{array}$ & $\begin{array}{l}\text { 1. The design is less } \\
\text { practical because } \\
\text { the size is too } \\
\text { thick and hard to } \\
\text { keep in the pocket } \\
\text { 2. The placement of } \\
\text { the button should } \\
\text { be noted }\end{array}$ & $\begin{array}{l}\text { The design is } \\
\text { thinned, re- } \\
\text { duced size and } \\
\text { customized no- } \\
\text { tification button }\end{array}$ \\
\hline $\begin{array}{l}\text { Uses of } \\
\text { U-Qoser- } \\
\text { lin }\end{array}$ & $\begin{array}{l}\text { 1. The working } \\
\text { principle of the } \\
\text { too are not yet } \\
\text { clear } \\
\text { 2. Tool notification } \\
\text { are not yet correct } \\
\text { 3. The working } \\
\text { princple has } \\
\text { not crearly } \\
\text { distinguished and } \\
\text { detected of the } \\
\text { objects. }\end{array}$ & $\begin{array}{l}\text { 1. The work- } \\
\text { ing principle } \\
\text { is made suc- } \\
\text { cictinly in the } \\
\text { manual book. } \\
\text { 2. Notification } \\
\text { button using } \\
\text { braille letters } \\
\text { 3. Differentiated } \\
\text { sound varia- } \\
\text { tion correspon } \\
\text { to soling ob- } \\
\text { ject distance }\end{array}$ \\
\hline $\begin{array}{l}\text { Feasibil- } \\
\text { ity of U- } \\
\text { Qoserlin }\end{array}$ & $\begin{array}{l}\text { The U-Qoserlin tool } \\
\text { should be devoted to } \\
\text { one object }\end{array}$ & $\begin{array}{l}\text { Specification } \\
\text { tool only to de- } \\
\text { tect solid ob- } \\
\text { jects }\end{array}$ \\
\hline
\end{tabular}

$\mathrm{VP}=$ Very Practical; $\mathrm{P}=$ Practical; $\mathrm{LP}=$ Less Practical; VU = Very Useful; $\mathrm{U}=$ Useful; $\mathrm{LV}=$ Less Useful; VG = Very Good; G = Good; LG = Less Good. After the revision of U-Qoserlin, then obtained the specification of U-Qoserlin for developed, namely: (1) rectangular shape; (2) $7.5 \mathrm{~cm}$ long, $5 \mathrm{~cm}$ wide, $2.6 \mathrm{~cm}$ thick; (3) there is a white on button and braille writing to be pressed during orientation and mobility activities; (4) has 2 ultrasonic sensors; (5) makes a loud notification sound; and (6) use the battery.

While the working principle of U-Qoserlin Tools is: (1) user turns on the appliance by pressing on button once, then tool will live as long as user use it; (2) the device will sound a slow tap if the solid object distance from the user is more than 1 meter; (3) if the user approaches a solid object with a distance of more than 1 metre then the notification sound reads one first knock of the opening; (4) if the user gets closer to a solid object accompanied by two taps with a fast sound; (5) if the tool does not provide voice notification (without sound) then it means the user is not near the solid object.

The second stage of the research is a U-Qoserlin Toolkit test to the visionary obstetrician in SLB N 2 
Padang, SLB Wacana Asih Padang, and SLB Gema Insani Padang. The results showed that the value of Uhit of 7.5 as the smallest $U$ value is Utab at a significant level of $95 \%$ and $\alpha=0.05$ for $n=5$ is 2 . Thus, it can be concluded that the U-Qoserlin tool can improve the ability to detect solid object distance on the person with visual impairment.

\section{Discussion}

The results of this study prove that U-Qoserlin Tool has the value of practicality, usability, and feasibility to be used by people with visual impairment. After testing to the person with visual impairment, the result showed that U-Qoserlin Tool can improve the ability to detect solid object distance. This is because it has a practical and interesting design, as a focused orientation and mobility tool for object distance detection, has a clarity of usage guidelines, there is braille writing on the tool to facilitate the user, easy to operate the tool, light and easy to keep in the pocket, and improve user confidence.

The results of this study support the independence program of persons with visual impairment in mobility. The results of this study supported by Marlina (2014) that one of the forms of independence is in the field of social and mobility. The key to successful implementation of inclusive education for children with special needs, including children with visual impairments is to have good mobility and social skills. Good social skills are supported by mobility skills. For people with vision impairments, mobility skills become a prerequisite for success in the wider environment.

Every product that is made certainly has advantages and disadvantages. For the creative, critical, and an innovative young generation that is fixing deficiencies in accordance with the times to be more comfortable to use. Similarly, the products that researchers develop in addition to the quality possessed by U-Qoserlin tools, there are also disadvantages of the developed product that is: (1) has not been able to detect the gutters ; (2) has not been able to detect a slippery surface; (3) can only detect the distance of pre-programmed objects; (4) has not been able to detect the surrounding terrain.

The results of the reflection obtained through interviews on vision barriers about mobility aids on manual rods are not electronically based, are less practical in use and reduce self-esteem for visually impaired persons. The results of the developmental on the research of U-Qoserlin device testing have been described for its own qualities and weaknesses for U-Qoserlin tools. After the use of trials to people with visual impairments in three schools SLB Negeri 2, SLB Wacana Asih and SLB Gema Insani Padang, products that researchers developed can be well received and help orientation and mobility.
The conclusion that can be drawn from the findings of this research is based on the development stage and the revision phase of the product ie the improvement of the product according to the suggestion from the relevant experts, that U-Qoserlin equipment is practical because it has a portable design, useful and feasible for visually impaired, capable detects solid object spacing, and adds vision insider insights about electronic mobility-based tools. Therefore, it is suggested that the researchers further develop different devices, more effectively and efficiently in all conditions and situations for the person with visual impairment.

\section{CONCLUSION}

Based on the research, it can be concluded that U-Qoserlin tools are practical, feasible, useful and provide technological insights for the person of visually impaired; The U-Qoserlin tool effective in improving the ability to detect solid object spacing for the person of visually impaired.

It is better for the next researcher to do the test of the effectiveness of U-Qoserlin on the number of the person of visually impaired more.

\section{REFERENCES}

Aktanto, M. (2016). Multi Ultrasonic Electronic Travel Aids (MU-ETA) sebagai Alat Bantu Penunjuk Jalan bagi Tuna Netra. Biosains, 18(2).

Dwiono, W., Posma, S. N., \& Gunawan, A. (2014). Embedded System Application for Blind People Navigation Tool. Indonesian Journal of Electrical Engineering and Computer Science, 12(8), 60836087.

Marlina, M. (2014). Keterampilan Sosial Anak Berkesulitan Belajar di Sekolah Dasar Inklusif. Penelitian Pendidikan, 5(1).

Qoniah, S. (2016). Pengembangan Alat U-Qoserlin Yuqon Sensor for the Blind untuk Pendeteksi Jarak Objek (Research and Development). Skripsi Tidak Diterbitkan. Padang: Fakultas Ilmu Pendidikan, Universitas Negeri Padang.

Rahayu, T. M. (2012). Perancangan Dan Pembuatan Penunjuk Arah Serta Deteksi Jarak Benda Untuk Tunanetra Dengan Output Suara Berbasis Mikrokontroler. Jurnal Neutrino, 3(1).

Sharma, P., SL, M. S., \& Chatterji, S. (2014). Design of micro controller Based Virtual Eye for the Blind. International Journal of Scientific Research Engineering \& Technology (IJSRET), 3(8).

Subandi. (2009). Alat Bantu Mobilitas untuk Tunanetra Berbasis Elektronik. Jurnal Teknologi, 2(1). 
162 Journal of ICSAR; Volume 2, Number 2, July 2018: 158-162

Sugiyono. (2014). Metode Penelitian Kuantitatif, Kualitatif, dan R\&D. Bandung: Alfabeta.

Tangdiongan, R. C., Allo, E. K., \& Sompie, S. R. (2017). Rancang Bangun Alat Bantu Mobilitas Penderita Tunanetra Berbasis micro controller Arduino Uno. E-Journal Teknik Elektro dan Komputer, 6(2), 7986. 